\title{
Chorological synopsis of genus Salix L. in the Iberian Peninsula
}

\section{Paloma Blanco}

Real Jardín Botánico, CSIC, Plaza de Murillo 2, 28014 Madrid, Spain

The distribution map of every willow species growing in Spain and Portugal has been proposed, in UTM projection with points equivalent to $10 \times 10 \mathrm{~km}$ squares. The study of this material has revealed that the species of Salix occurring in the Iberian Peninsula show similar characteristics and difficulties to those seen throughout the rest of Europe. The species covered are:

Subgenus Salix: (Salix triandra L. (S. amygdalina L.), S. pentandra L., S. alba L., S. fragilis L., Salix alba $\times$ fragilis ( $S$. neotricha Goerz), S. babylonica L.).

Subgenus Chamaetia: ( $S$. reticulata L., S. herbacea L., S. retusa L., S. pyrenaica Gouan, a Pyrenean endemic, $S$. breviserrata Flod.).

Subgenus Vetrix: (S. hastata L., S. pedicellata Desf., S. caprea L., S. atrocinerea Brot., $S$. aurita L., $S$. salvifolia Brot., an endemic in the western half of the Iberian Peninsula, S. tarraconensis Pau, an endemic of the limestone mountains in the border between the provinces of Tarragona and Castellón, $S$. bicolor Willd., $S$. cantabrica Rech. fil., S. viminalis L., S. eleagnos Scop., S. lapponum L. (subsp. cereana Montserrat?), S. daphnoides Vill., S. repens L., S. purpurea L.).

\section{Bud formation and sprouting pattern of coppice shoots in some North American and European willows}

\section{Sennerby-Forsse ${ }^{1}$ and L. Zsuffa ${ }^{1,2}$ \\ ${ }^{1}$ Swedish University of Agricultural Sciences, Department of Ecology and Environmental Research, Box 7072, S-750-07 Uppsala, Sweden and 2University of Toronto, Faculty of Forestry, Forest Genetics Laboratory, 33 Willcocks Street, Toronto, Ontario, Canada M5S 3B3}

Fast-growing willows are propagated as coppice in short rotation biomass plantations for energy and pulp. A number of internal and cultural factors influences the development and growth of new shoot generations from harvested stools. The morphological and structural basis for resprouting were studied in Salix viminalis L., subgenus Vetrix, section Vimen, S. eriocephala Michx., subgenus Vetrix, section Cordatae and S. amygdaloides Anderss., subgenus Salix, section Humboldtiana, and tested for short rotation forestry programmes. The initiation and development of buds, bud morphology, location and abundance of buds and the resprouting pattern after coppice treatment were investigated. All buds were axillary in origin and consisted of one main shoot primordium and two lateral primordia. The number of buds and their location were strongly correlated to number of developing shoots in all species. In $S$. viminalis and $S$. eriocephala the lateral buds at the basal portions of the stems contained several leaf primordia and usually sprouted shortly after the main bud in response to coppice treatment. In $S$. amygdaloides the further development of the lateral buds was inhibited after the formation of bud scales. The 